\title{
"Med karameller og bilblad som arbeidsredskap"
}

\author{
Svein Skarholm intervjues av Dag W illy Tallaksen.
}

\begin{abstract}
Som sosialpedagogisk rådgiver ved Skedsmo videregående skole er Svein Skarholm tilgjengelig for elevene i skoletida. Elevene kjenner ham og kan stikke innom uten å ha noe spesielt på hjertet. Har de tidligere slått av en prat, kan det vaere lettere å komme igjen hvis de skulle få problemer. Mange ungdommer opplever motgang for første gang i livet når de begynner på videregående. Det kan vaere kjaerlighetssorg, dødsfall i familien eller naermiljøet, eller følelsen av ikke å strekke til på skolen. Skarholm understreker at det da er viktig å vaere tilgjengelig. Det gjelder å få fatt i dem som sliter før de får utviklet alvorlig depresjon, eller en annen alvorlig diagnose.
\end{abstract}

- Det er tvingende nødvendig å være direkte, sier Skarholm. Får jeg en anelse om at den ungdommen jeg snakker med bærer på noe som kan være tanker om selv-mord, så spør jeg rett ut om han eller hun har selvmordstanker. I stedet for å tolke må vi spørre direkte. $M$ in resept for å oppnå kontakt er å være synlig, tilgjengelig, ufarlig og direkte i samtale med unge mennesker. Som i eventyrene er det gjerne slik at både "trollet" og selvmordstankene sprekker når de kommer ut i sollyset. Som voksne må vi formidle håp til ungdommene.

0 ptimisme, håp og ufarlig nærvær er gjennomgangstonen i samtalen med Skarholm. Kontoret hans gir signaler om at hit er det helt i orden å komme innom for å snakke om det man måtte ha på hjertet. H er kommer da også mange som bare vil slå av en prat. Det er ikke nødvendigvis problemer som bringer elever til Skarholmskontor. D et kan gjerne være interessen for å se på siste utgave av et av bilbladene hans og/eller en samtale om biler og motorer. - Jeg må tilstå at jeg er en smule bilgal, innrømmer han. N oen kommer tilbake ved en senere anledning, fordi de har det vanskelig.

Skedsmo videregåen de skole ligger i utkanten av Lillestrøm, cirka 3 mil øst for 0 slo, og har i alt 700 elever ved både allmenn- og yrkesfaglige studieretninger. At elevene vet hvor han holder til, ble tydelig allerede i vestibylen hvor undertegnede spurte en tilfeldig gruppe ungdommer om veien til Skarholmskontor. - O pp trappen og til venstre, kom det lynkjapt. På bordet ligger det bilblader. En skål fylt med karameller er også innen rekkevidde. - H er er døren alltid åpen. Fordelen med min stilling er at jeg har mindre undervisningsplikt enn andre lærere. Det er viktig i min rolle å gi signaler om at jeg har tid, at jeg ikke alltid er på vei til en ny undervisningstime, sier Skarholm.

Skarholm har vært prest siden 1977 og har variert erfaring fra arbeidslivet. Både Forsvaret, menigheter og skoler har vært hans arbeidsarenaer. I tillegg har han pastoralklinisk utdanning fra M odum. N ylig hadde han studiepermisjon, og arbeidet da med temaet "U ngdom, depresjon og selvmord".

- U ngdomstiden kan for mange unge være svært vanskelig, og det er en tid hvor kontakten med voksenverdenen kan være komplisert. Foreldre ser sine ungdommer deler av døgnet og nærer kanskje bekymring for det de ser, men făr ikke alltid til å bryte igjennom en vanskelig overflate. U ngdom tilbringer mye av sin tid på skolen, og her ser vi lærere også om ungdommene sliter. Jeg bruker bevisst mye av min tid på å være sammen med elevene. G år om nødvendig inn i miljøer som kan virke både avvisen de og aggressive. Det er mye innsikt å hente om ungdomsmiljøet ved å vandre rundt og være tilgjengelig. Elever med mye fravær og fall i karakternivå blir positivt tatt fatt i. A t noen voksne bryr seg slik at el ever ikke får anledning til å skjule seg og sine vansker er viktig. D et meste kan det gjøres noe med, ofte med forbausen de enkle midler. Første bud er at vi klarer å fange opp de som sliter med selvmordstanker og annet som det kan være vanskelig å snakke om. Deretter må vi hjelpe dem til å få satt ord på det vanskelige, for så å formidle håp. Voksne må imidlertid ha kunnskap for å kunne se og å vite hva de skal se etter. $\AA$ spørre om selvmordstanker er ofte som å dra ut en plugg. U ngdommene blir lettet over at noen bryr seg og vil lytte til det de sliter med. A formidle håp om at det finnes hjelp, at man ikke er alene med å ha det vanskelig, er god førstehjelp. Litt praktisk støtte på veien inn mot hjel peapparatet er ofte også noe som blir satt pris på.

- "W alk and talk", sier Skarholm og peker på at det for mange, spesielt unge gutter, er vanskelig å sitte stille og snakke om følelser. - Det kan være under en spasertur eller på vei til kino at det endelig går hull på byllen og de vanskelige følelsene kommer fram og ut. U nge aggressive gutter er ikke alltid slik de ser ut. Bak aggresjonen finnes ofte en dyp fortvilelse. H er er gutter og jenters språk forskjellig. Løsningen er derfor ikke å utvise den aggressive unge gutten fra skolen før det er gjort et helhjertet forsøk på å finne ut hva som ligger bak. A propos språk, ungdommene har sin egen måte å uttrykke seg på. På sett og vis har de et eget språk. Vi skal ikke snakke ungdommenes språk, men det er viktig at vi forstår det.

- M in alder (litt over 50 år), min livserfaring, samt det faktum at jeg er mann, er en fordel i denne jobben. Litt på utsiden av det faglige er han også, noe som gjør at det er lettere å betro seg til Skarholm uten at det får konsekvenser for lærer-elev-forholdet. H er kommer også en annen av Skarholms uvanlige arbeidsmetoder fram. H an tar gjerne kveldene i bruk. - Det er vel presten i meg som gjør at kontortiden ikke oppleves som tilstrekkelig. Dessuten, ungdommene lever jo også om kvelden og natten. Det er mye misbruk av rusmidler i enkelte miljøer. A lkohol, hasj og partydop er i bruk spesielt i helgene. For noen bare øker dette vanskelighetene.

$\mathrm{N}$ oen av de som har det vanskeligst, vet at de kan kontakte Skarholm når på døgnet det måtte være. Denne tilliten er så langt ikke blitt misbrukt. - U ngdom er flotte i så måte. N oen unge har det så vanskelig og har så kompliserte forhold til sine familier at tilbudet har vært helt nødvendig, legger Skarholm til.

$H$ va så med forholdet til det etablerte hjelpeapparatet? - H elt uproblematisk, sier Skarholm. - N år en ungdom forteller om vansker som er så store at det er nødvendig å involvere hel sevesenet, hjelper jeg gjerne til med å kontakte enten helsesøster eller fastlege, dersom eleven selv vil. Jeg har gode erfaringer i så måte. 
U ngdommene vet at jeg har taushetsplikt, men enkelte ganger må vi bare videre med vanskene. $\mathrm{N}$ oen elever må ha helsefaglig hjelp og oppføl ging over lang tid. Det ligger mye håp i å vite at hjel peapparatet har noe å tilby, og at man faktisk ikke den eneste eller første som har slitt med vanskeligheter i ungdomstida. N oen ganger har dette ført fram til innleggelse i psykiatrisk avdeling pga. selvmordskrise.

Som nevnt er Skarholm prest i Den norske kirke. Det forhindrer ikke at han blir oppsøkt av ungdommer fra forskjellige kulturer og med ulik religiøs tro. Her er han hele skolens rådgiver. $M$ ange unge er opptatte av eksistensielle spørsmål, om tro og tvil og meningen med livet. - Dette er jo tema min bakgrunn som prest har gitt meg lang erfaring i å snakke om. Ved å fremstå som åpen og ærlig tror jeg ungdommene vet hvor de har meg. Jeg forsøker å legge vekt på å være lydhør og sensitiv. Et viktig poeng til slutt: Jeg liker å være sammen med ungdom og formidler at jeg er glad i dem. U ngdommene våre er flotte, legger Skarholm til.

Det er muligens ikke helt tilfeldig at det også står et klassisk førstehjelpsskrin på hans kontor!

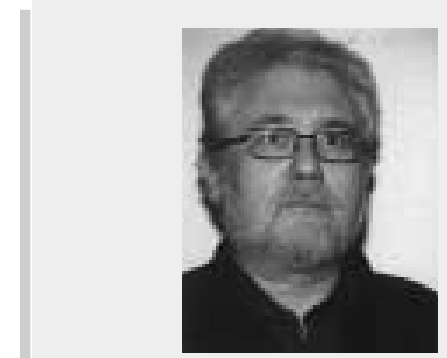

Svein Skarholm:

$\mathbf{R}$ ådgiver med hovedansvar for sosialpedagogiske saker

- Bistår elever som har personlige eller sosiale vansker som har betydning for skolearbeidet

- M edvirker til at det etableres et godt samarbeid med foreldre/ foresatte og andre institusjoner utenfor skolen

- Følger opp elever med stort fravær

- H ar ansvar for holdningsskapende arbeid innen vold, rus og mobbing

- H ar ansvar for å jobbe med bekjempelse av fordommer, diskriminering og rasisme.
(Forts. fra s. 13 - VIP-prosjektet)

\section{Fremdriftsplaner}

Det er i løpet av prosjektperioden kommet forespørsler fra ulike deler av landet om å få del i prosjektet. V i er i gang med opplæring til fylkene Sogn og Fjordane og H edmark. D ette gjelder opplæring av personell som skal kunne gjennomføre opplegget i eget fylke der helsepersonell, Iærere og PP-tjenesten deltar. Det unike er at skoleetat v/ utdanningsdirektør og helseetat v/fylkesmann sammen kjøper rettigheter og opplæring fra VIP sentralt ved Blakstad sykehus, til anvendelse i eget fylke. Dette tverretatlige samarbeidet kommer ungdommene til gode.

Vi erfarer at VIP-prosjektet er et godt selvmordsforebyggende arbeid med åpenhet for ungdommenes virkelighet i sårbare perioder. Det innebærer at sterkt fortvilte ungdommer vet hvor de kan få hjelp av voksne, og at videre hjelp også kan tilbys.

A nne $\mathrm{G}$ ro T vedt er spesial konsulent i forebyggende arbeid ved Sykehuset A sker og Bærum $\mathrm{H} F$, divisjon Blakstad sykehus. For mer informasjon kontakt: annegro.tvedt@blakstad-sykehus.no

Internett: www.vipweb.no

(En egen artikkel om prosjektet stod i Suicidologi 2001, nr. 3, www. med. uio. no/ipsy/ssff/tids0103/T vedt.

\section{Nye bøker}

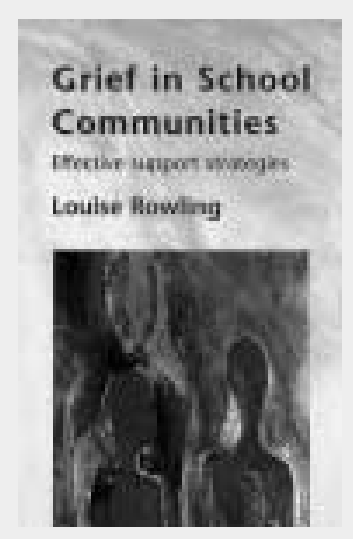

Rowling, Louise:

$G$ rief in school communities: effective support strategies

Buckingham: 0 pen U niversity

Press, 2003. - $196 \mathrm{~s}$.

ISBN 0-335-2115-1

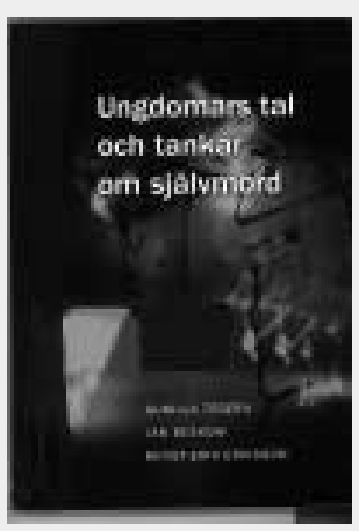

Tegern, G unilla / Beskow, Jan / Eriksson, Bengt-Erik:

\section{U ngdomars tal och tankar om självmord}

Lund: Studentlitteratur, 2003. ISBN 91-44-02819-9

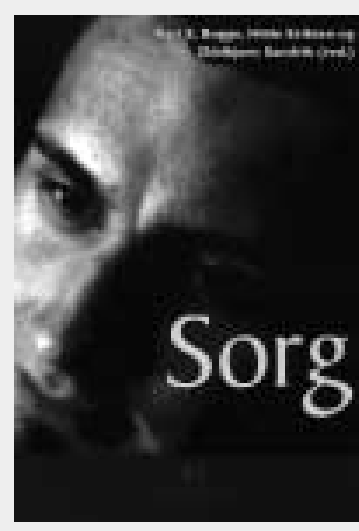

Bugge, Kari H . / Eriksen, H ilde / Sandvik, O ddbjørn (red.)

\section{Sorg}

Bergen: Fagbokforlaget, 2003.

- 237 s. ISBN 82-7674-708-6 